\title{
The Evolution of Digital Transformations: A Literature Review
}

\author{
Justin Goldston, PhD
}

\begin{abstract}
Enterprise applications are complex architectures that assist leaders of organizations to make tactical and strategic business decisions. Many of the studies in the literature review investigated the history of ERP systems, the future of enterprise applications, implementation success, ERP implementations in small and medium environments, and managerial approaches during times of organizational change. The purpose of this literature review was to analyze and synthesize previous studies as they pertain to enterprise applications.
\end{abstract}

\section{INTRODUCTION}

As computers were introduced in the 1960s, organizations began to develop applications to track inventory, assist in ordering materials, and produce finished goods. In a concept identified as inventory control, firms took the first step in systematically running the operational side of their organization (Jacobs \& Weston, 2007; Thakur, 2016). In the 1970s, Materials Requirements Planning (MRP) applications were introduced to enable organizations to purchase, forecast, and schedule production, spawning the founding firms of the industry such as SAP and J. D. Edwards (Egdair, Rajemi, \& Nadarajan, 2015; Jacobs \& Weston, 2007; Singh \& Nagpal, 2014). With the number of organizations creating additional requirements to reduce their overhead costs, J. D. Edwards enhanced their MRP applications to include closed-loop scheduling, enhanced shop floor reporting, and forward scheduling known as MRP-II (Jacobs \& Weston, 2007; Kumar \& Van Hillegersberg, 2000). As organizational leaders began to revert to technology to assist in daily operational decisionmaking, by the end of the 1980s, the primary ERP vendors were established - SAP, IBM, J. D. Edwards, Baan, PeopleSoft, and Oracle (Razzhivina, Yakimovich, \& Korshunov, 2015). With enterprise applications enabling decision-makers to provide better visibility of their inventory and production levels, organizations also looked to these applications to set themselves apart from their competition.

In the 1990s, with the market becoming more competitive, the major players looked for a competitive advantage and began to release applications that integrated the operational portion of the organization with the accounting area of the firm (Bhuiyan, Chowdhury, \& Ferdous, 2014). Coined ERP by the Gartner Group, this new technological development spurred immense growth with the core six business application vendors (Jacobs \& Weston, 2007). With the fear of the unknown approaching for the year 2000 with Y2K, ERP industry marketing caused firms to scramble to install these applications sparking dramatic growth in ERP vendors and offerings (Brumberg et al., 2016; Salimi, Dankbaar, \& Davidrajuh, 2015). When the dotcom bubble of 2001 rocked the entire technology industry, the major players in the industry were pressured to downsize (Fadlalla \& Amani, 2015). By the end of the 2000s, the ERP landscape changed as J. D. Edwards, and PeopleSoft were acquired by Oracle (Palanisamy, Verville, \& Taskin, 2015) and a new entrant in the market, Infor Global Solutions acquired Baan (Verdouw, Robbemond, \& Wolfert, 2015) and IBM's MAPICS product (Banerjee, 2015), resulting in SAP, Oracle, and Infor becoming the top three ERP vendors in the market respectively.

In reaching the maturity stage of its lifecycle, ERP applications have continued to progress with the gradual introduction of cloud computing. Cloud computing reduces the information technology (IT) overhead for firms by moving all hardware to support its ERP application off premise to a vendor-hosted site (Bento, Bento, \& Bento, 2015). In a 2016 ERP Report performed by Panorama Consulting, the survey of 215 organizations deploying ERP applications uncovered a $40 \%$ increase in firms implementing cloud versus on-premise solutions compared to 2015 (Solutions, 2016). To analyze the dramatic increase, the reduced misconceptions of cloud computing also led to the dramatic increase (Solutions, 2016). As ERP providers continue to increase application security to mitigate the risk against security breaches, more organizations are moving from on-premise solutions to cloud-based offerings.

In addition to cloud computing, in an effort to reduce waste within operations, the supply chain community instituted Lean initiatives over the past decade which were also integrated into ERP applications (De Soete, 2016). In an effort to develop a tool to track sustainable processes, researchers have begun to call these new applications Sustainable Enterprise Resource Planning (S-ERP) applications. As the next phase of business applications, the premise of the next section focuses on how S-ERPs can positively impact all three aspects of an organization's TBL, as well as global sustainability. Refer to Table 2 for a graphical representation of the evolution of business applications. 
ISSN No:-2456-2165

\begin{tabular}{|c|c|}
\hline Decade & Applications \\
\hline $1960 \mathrm{~s}$ & Early computers, Reorder point systems, and early Materials Requirements Planning (MRP) \\
\hline $1970 \mathrm{~s}$ & MRP \\
\hline $1980 \mathrm{~s}$ & MRPII and early Enterprise Resource Planning \\
\hline $1990 \mathrm{~s}$ & ERP \\
\hline $2000 \mathrm{~s}$ & Sustainable Enterprise Resource Planning (S-ERP) \\
\hline The future & \\
\hline
\end{tabular}

Table 1:- The Evolution of Business Applications

\section{The Birth of S-ERP}

As firms become more innovative and socially conscious, leaders are utilizing technology to integrate sustainable operations, processes, and information through knowledgesharing within their organization. Sustainable development and production can be characterized as development that fulfills current requirements of individuals without compromising the requirements of individuals in the future (De Soete, 2016). As business partners of global firms continue to question whether their supply chains and productions facilities are sustainable and safe (De Soete, 2016), these companies have vowed to become environmentally sustainable. To document their efforts, these companies are working with ERP providers to modify their current applications to create modules to track their information. Zvezdov and Hack (2016) performed a study of a multinational food company that created a carbon information management (CIM) module within their ERP system to track carbon emissions across their portfolio of operating facilities. In addition to carbon emissions tracking, De Soete (2016) provided the following examples of how organizations can utilize their existing business applications to make more sustainable decisions:

- Utilizing a product's bill of materials to track plastics and solvent use

- Tracking the time duration of a chemical synthesis step

- Analyzing the energy consumption of a production line

Although initial steps have been taken to develop S-ERP applications, with the failure rates of traditional ERP implementations ranging in the area of $60 \%$ (Maas, Fenema, \& Soeters, 2014; Ravasan \& Mansouri, 2016), the adoption of S-ERP applications could be even more complex to implement (Chofreh et al., 2016). With new data types, data, and stakeholders such as environmentalists and scientists of a firm that previously would not have interacted with the ERP application, Chofreh et al. (2016) posited that the implementation of S-ERP applications would be new territory for firms.

The foundation of traditional ERP applications is built upon optimizing operational and financial processes resulting in increased profits. In an S-ERP world, all facets of the TBL are covered within an organization, which in turn will affect all stakeholders of an organization (Chofreh, Goni, Shaharoun, Ismail, \& Klemeš, 2014). In comparing the two applications, the philosophy of traditional ERP systems focuses primarily on profit to centralize all data and decision-making functions within one application. With S$\mathrm{ERP}$, the primary focus is on the TBL, which is composed of profit, people, and planet (Ahmad \& Mehmood, 2015; Gianni, Gotzamani, \& Tsiotras, 2017). Profit within the TBL refers to value-added activities performed within an organization (Chofreh et al., 2014). The people component refers to a firm's most important asset, the employees. Finally, planetrefers to the environment, and the world's natural resources (Chofreh et al., 2016). Although the environmental impact has not yet been fully realized with a phased sustainability approach, organizations can leverage technology to make a positive impact on social change.

\section{$>$ Implementing S-ERP Applications}

As Information Technology (IT) projects have varying methodologies, S-ERP applications could be implemented utilizing similar approaches (Chofreh et al., 2016). Referring to the proposed S-ERP implementation methodology as the S-ERP master plan, this plan would shorten the implementation timeline, cost, and resources (Chofreh et al., 2016). In developing a structured approach, risk can be mitigated throughout the implementation lifecycle. Similar to other implementation methodologies, the S-ERP methodology has three parts - the project roadmap, the application framework, and the project guidelines. In reviewing recent studies, a gap was uncovered regarding the outcome of successful S-ERP implementations. In scoping out the proposed architecture of an S-ERP application, obtained with permission, Figure 3 depicts the complexity of this application. While decision-makers in firms can utilize existing technology using the tools and information they currently have at their disposal, the following caveats could be identified regarding the implementation of S-ERP applications:

- Data management in organizations

- Data penetrations through ERP systems consistency in data logging

- Supply chain transparency

- Supply chain reliability

- $\quad$ The language (and education) issue (De Soete, 2016)

While leaders of organizations speak to supply chain concepts from a theoretical perspective, these leaders could move toward advanced sustainable technology to put these theories into practice. 
SUSTAINABLE ERP SYSTEM

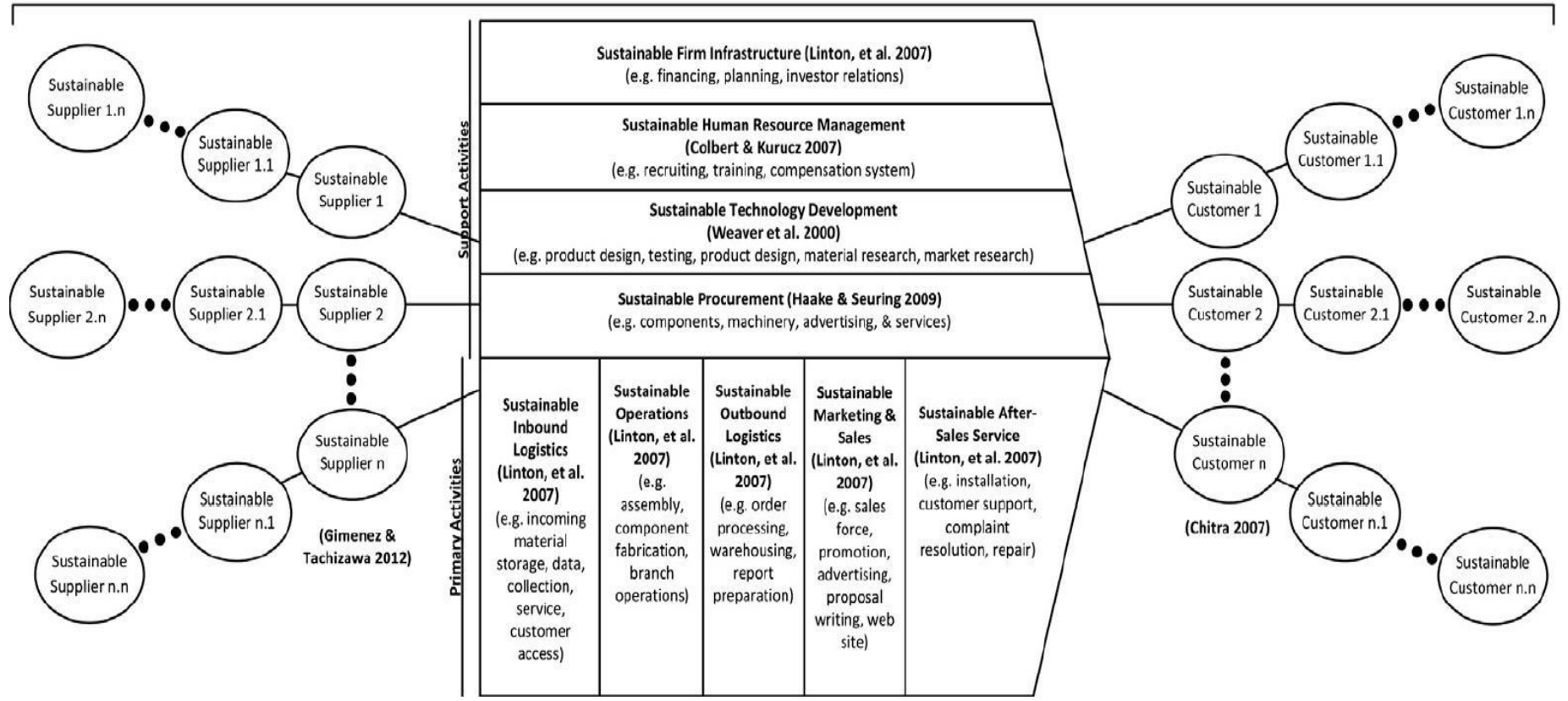

Fig 1:- Proposed S-ERP system with modules. Adapted from "Sustainable Enterprise Resource Planning: Imperatives and Research Directions” by A. G. Chofreh, F. A. Goni, A. M. Shaharoun, S. Ismail, and J. J. Klemeš, 2014, Journal of Cleaner Production, 71, p. 141. Copyright 2014 by Elsevier Limited.

\section{ERP Systems in Small and Medium Business Environments}

Although ERP systems were initially developed to run large scale enterprises, SMEs are increasingly motivated to introduce ERP implementations (Upadhyay, Basu, Adhikary, \& Dan, 2010). Small and medium enterprises are represented by a range of inherent characteristics that distinguish them from large enterprises, such as ownership type, structure, culture, and market (Amba \& Abdulla, 2014). Concerning the issue of IT/IS adoption, limited resources, limited IS knowledge, and the lack of IT expertise are constraints facing SMEs in implementation projects (Bansal \& Agarwal, 2015). In an SME environment, once approved, a full annual IT budget could be spent on ERP implementation efforts (Hsu, Ray, \& LiHsieh, 2014). Researchers found that ERP implementation costs, as a percent of revenue, range from $0.82 \%$ for large firms compared to $13.65 \%$ for SME firms due to economies of scale working for the larger firms (Bohórquez \& Esteves, 2008).

Major SME projects face increased external and internal risks when compared to large organizations. Externally, SMEs are more fragile than large companies and face greater difficulty in obtaining credit (Zach \& Munkvold, 2012). Such external risks could lead SMEs to delay the project of ERP implementation or forego it altogether. Internally, SMEs may find it difficult to implement reengineering projects due to limited resources. Overall, SMEs may face greater challenges in adopting technology as compared to large enterprises given the constraints mentioned above (Zach \& Munkvold, 2012).
Given the hidden costs of ERP implementations, SMEs should understand the total cost of ownership of an ERP application before embarking on a project of this magnitude. Successfully implemented, ERP applications allow an organization to gain a competitive advantage by saving resources and by responding to the ever-changing business environment (Mahdavian, Wingreen, \& Ghlichlee, 2016; Sudhaman \& Thangavel, 2015). Additionally, a successfully deployed ERP system can increase customer satisfaction, reduce inefficient spending, strengthen sales and forecasts, reduce inventory turn-around times, and enhance employee productivity (Maas et al., 2014). Because large enterprises have been implementing ERP solutions since the mid-1990s, SMEs view an ERP solution as the answer to set them apart from the competition - but this belief could be due to their lack of experience and knowledge of ERP implementations. If leaders of SMEs continue to implement these applications without education, unless the differences between SMEs and large enterprises are clearly conceived, ERP implementations may continue to be painful and unfruitful for SMEs (Huin, 2004).

\section{$>$ Managerial Theories in ERP Implementations}

Although researchers have outlined various critical failure factors in the literature, management and leadership approaches are identified as failure factors in ERP implementations (Elkhani, Soltani, \& Ahmad, 2014; Mitra $\&$ Mishra, 2016). Although prior research focused on ITrelated theories such as the task-technology-fit (TTF) theory and the DOI theory (Pishdad, Koronios, Reich, \& Geursen, 2014), researchers still identify a gap between leadership theories and ERP implementation risk. In the 
next section, leadership theories, and how they can be integrated into CSFs in ERP implementations are reviewed.

Transformational leadership theory. Leaders are instruments of transformation exerted through the followers or employees to bring about change in governance and productivity (Dunn, Lafferty, \& Alford, 2012; GarcíaMorales, Jiménez-Barrionuevo, \& Gutiérrez-Gutiérrez, 2012). First introduced by Burns (1978), transformational leadership can be characterized as the ability of a leader to inspire employees to perform work beyond their expectations (Elkhani et al., 2014). When leaders of organizations embark on an ERP implementation, they are performing an internal business process reengineering (BPR) initiative. With this new project, firms should appoint a leader to the project that is equipped with BPR skills and has experience in being a change agent (Mitra \& Mishra, 2016).

In research on change management during ERP implementations, Iveroth (2016) found that change management should be at the top of executive's strategic agenda and the leaders should refer to the empirical experience of internal and external resources. Also, during this time of change, leaders should act as transformational managers and focus on continuous improvement even after the project is closed (Iveroth, 2016). Although the external consultant working with the leader most likely has these skills, an internal change agent may be included on the implementation team to influence and lead operational decisions.

In portraying the following traits, transformational leaders can inspire, encourage, empower, and influence project team members to work toward the common objective of a successful implementation. When leaders encourage creativity through transformational leadership, users are more likely to experiment with the system features, enabling them to learn the system more quickly (Elkhani et al., 2014). Additionally, transformational leadership can create a higher level of psychological empowerment (PE), commitment to the project, and trust (Mittal, 2016).

Leadership and organizational change will help develop leaders and managers to adapt to change and complex situations. Valuable information for future leaders involves continued training in specialized areas such a communication, adapting to change, complex situations, and effective leadership and management skills. Research has shown a large percentage of leaders lack global leadership skills, and less than ten percent of organizations have a program in place to fulfill this gap (Minner, 2015). Regarding the future of management, there is room left for improvement that will be achieved through transformational leadership.

Servant leadership theory. Another leadership theory that is compared to transformational leadership is servant leadership. In comparing the two theories, it has been found that transformational leaders focus on organizational objectives while servant leaders focus on people as followers (Elkhani et al., 2014). Introduced by Greenleaf (1970, 1977), servant leadership includes ethics, virtues, and morality and has been noted as a model that may assist a leader in dealing with issues that arise within an organization. The primary objective of a servant leader is to empower followers to make a positive impact on the organization (Flynn, Smither, \& Walker, 2015). Servant leaders are more empathetic than transformational leaders and incorporate emotional intelligence (EI). Kennedy (2012) found that EI has more importance to multicultural leadership than task-related knowledge or IQ. An emotionally intelligent leader demonstrates the ability to, identify not only the emotions of others but also acknowledge personal bias. With EI, leadership becomes the base for servant leadership by promoting the strengths of others. In researching servant leadership qualities within ERP implementations, Krog and Govender (2015a) described five additional servant leadership dimensions: altruistic calling, emotional healing, wisdom, persuasive mapping, and organizational stewardship. In reviewing each of these dimensions as they pertain to projects, several studies revealed that persuasive mapping and altruistic caring would lead to employee empowerment, which in turn would harness innovative behavior, commitment, and trust (Hassan, Asad, \& Hoshino, 2016; Krog \& Govender, 2015b).

\section{$>$ Challenging Conventional Leadership}

Although leaders in various industries have shifted to transformational or servant leadership approaches, many leaders of small and medium organizations continue to follow conventional leadership methods (Larteb, Benhadou, Haddout, \& Nahla, 2016; Ndalila, Mjema, Kundi, \& Kerefu, 2015). As a conventional leadership culture is established by its leaders, to harness creativity and innovation to create a competitive advantage for an organization, leaders may consider a transition from conventional leadership (Chawla \& Sujatha, 2015). In the next section, approaches of how leaders have challenged conventional leadership will be reviewed (Acar, 2012).

Challenging conventional leadership with shared leadership. In the complex environment of increased global presence, conventional wisdoms and old managerial approaches are continually challenged. Leaders should be more improvisational and innovative as organizations leverage technology to gain a competitive edge over their competitors (Kasemsap, 2016; Ranjan, Jha, \& Pal, 2016). To expand on this philosophy, former General Electric Chief Executive Officer Jack Welch posited "if the outside environment is changing faster than the inside environment, the company is doomed" (Harvey \& Buckley, 2002, p. 371). Although there may not be a universal managerial approach, managers must analyze their current business environment, reflect on the organization's strategic vision, and act on complexities many organizations face in the late 2010s.

Mitra and Mishra (2016) stated that leadership is the most important factor in a successful or unsuccessful ERP implementation. Given ERP applications integrate all 
operational and financial functions of an organization, the traditional hierarchical leadership approaches have been proven unfavorable in these types of projects. With the cross-functional requirement of these engagements, a distribution of leadership may be required. The concept of shared leadership is a concept that has been studied at the executive and board member level in the past. To place shared leadership at the ERP project level, this approach could improve team effectiveness by sharing responsibilities which in turn could bring collaboration, trust, and mutual accountability (Le Pennec \& Raufflet, 2016). Given younger professionals are more technologically experienced, and more tenured professionals have years of managerial experience, a shared leadership approach could be implemented during ERP implementations. In following this approach, blending technical and managerial experience could lead to successful ERP implementations within organizations.

Challenging conventional leadership with sponsorleader exchange. Because ERP projects can last from 6 months to 2 years (Bansal \& Agarwal, 2015), power struggles could potentially arise among project leaders and team members. In the world of ERP implementations, the common misconception is that when one refers to a leader within a project, they are referring to upper-level management. In this case, the leader could be internal Project Manager, an external Project Manager or lead consultant, and organizational leaders are referred to as executive sponsors. With firms of all sizes implementing enterprise applications, leaders from different departments may be identified as the project leader resulting in various leadership styles. A managerial approach extensively researched in the area of leadership is known as leadermanager exchange (LMX). With this approach, leaders perform knowledge-sharing to provide the agreed upon vision of the firm's leadership team. LMX could lead to employee commitment and job satisfaction within an organization (Hall, Baker, Andrews, Hunt, \& Rapp, 2015).

In translating this approach to ERP projects, when the executive sponsor (corporate leader) assigns a project leader to the implementation, he or she must outline the reasons why the organization decided to embark on implementing a new business application in a concept that could be coined as sponsor-leader exchange (SLX). By instituting an SLX approach in an ERP implementation, the leader is not only sharing information with managers and employees, but they are also sharing responsibilities. This approach not only enables alignment throughout the organization's network, but it also increases the interpersonal trust between the centralized leadership, decentralized management, and employees of the organization (Scandura \& Pellegrini, 2008). In the implementation of SLX, project team members will have the ability to take the information regarding the executive sponsor's vision and knowledge of the application to other employees within the organization, enabling decentralized decision-making, empowerment, and job enrichment.
In reflecting on the transformational and servant leadership theories, one possible conclusion is the appropriate approach depends on the project and culture of the organization. To enhance the innovativeness and creativity within ERP implementations, firms can blend transformational and servant leadership (Elkhani et al., 2014). On the topic of challenging conventional leadership, shared leadership and SLX can share the responsibilities of the implementation to harness the experiences and creativity of all members of a project. In closing, while there is no one-size-fits-all approach, as the business landscape continues to change, firms must find innovative ways to mitigate risk and remain sustainable within their respective markets.

\section{$>$ Benefits of ERP Systems}

As the global market shrinks because of technological and logistical advances, leadership teams of organizations are looking for ways to make strategic decisions to maintain or increase their market share in their respective industries. To turn these systems into a competitive advantage, leaders of firms have utilized ERP systems to make their operational, tactical and strategic processes more efficient and effective (Shao, Wang, \& Feng, 2015). ERP systems are integrated, customized, and packaged software-based systems that handle the majority of system requirements in all functional areas of a business such as finance, human resources, manufacturing, sales and marketing (Lin, 2010). In addition to using ERP systems as a tool to make day-to-day business decisions, these systems can also be used as a tool to improve knowledge sharing within the organization. With ERP applications, organizations will enable departments and facilities to share knowledge and collaborate instead of operating out of disparate systems.

Technological benefits of ERP systems. With the rise of technology in the recent decades, ERP systems have made advances by shrinking the supply chain for organizations and their networks. ERP systems bring numerous competitive advantages to enterprises, including the reduction of business cost, quick response to customers, and the acceleration of corporate connections (Tsai, Li, Lee, \& Tung, 2011). Moreover, ERP systems can increase an organization's financial performance by reducing inventory turnover, increasing receivables turnover, and increasing profit margins.

In addition to internal advantages, these systems also impact social change by passing on cost savings, as well as communicating important information generated by these systems to the consumer. In various studies, researchers have found that ERP systems increase trading partner satisfaction with the use of the Supplier Relationship Management (SMR) and Customer Relationship Management (CRM) modules within the application. In one study, May, Dhillon, and Caldeira (2013) found ERP systems will ensure the ability for firms to understand customer desires to provide suggestions based on buying patterns generated by the application. With the increase in communication and visibility through the use of ERP 
systems, organizations can work closer with their partners to build stronger alliances.

Knowledge sharing benefits of ERP systems. Given ERP systems can be leveraged to positively impact management decisions, knowledge sharing can be included with the implementation of these applications. Knowledge sharing, also known as knowledge transfer, is defined as the process through which one organizational unit is affected by the experience of another as an event through which one entity learns from the experience of another (Rezania \& Ouedraogo, 2013). Typically, when organizations implement ERP systems, they will hire outside consultants that have the knowledge of the application, along with the familiarity of the industry best practices needed to successfully implement these solutions. Although selecting an experienced consultant is a critical success factor in the implementation and maintenance of an ERP system (Maditinos, Chatzoudes, \& Tsairidis, 2012), the effective transfer of knowledge is more vital. Jeng and Dunk (2013) found knowledge creation within a firm is a strong predictor of ERP success. As organizational leaders continue to build their knowledge base throughout the implementation lifecycle, they will increase the likelihood of a successful ERP installation.

Regarding social impact, companies are using technology to alert their vendors and customers of inventory levels, forecasts, etc., allowing these trading partners can better manage their supply chains. With this information, an organization's trading partners can be proactive in identifying demand spikes, enabling them to increase headcount by employing more members of their communities. While technology and knowledge sharing can impact positive social change within an organization, management and leadership also play an important role.

Leadership benefits of ERP systems. When leaders of organizations make the decision to bring new technology within an organization, management teams of these organizations play a key role in the decision-making process throughout the life of the implementation. For a new technology installation to be successful, management buy-in is one of the critical success factors. In one study, the researchers found that top management support is a prerequisite for the successful ERP system implementation (Maditinos et al., 2012). In another study, Lin (2010) concluded that top management support influences both perceived usefulness and ERP system usage. With the level of change of an ERP implementation, some leaders may encounter resistance from their workforce, which could indicate the need for a change in leadership approach.

Once an ERP application is installed, management support does not stop there. Just as with any operational process or procedure, the management team of organizations must practice continuous improvement methods to realize the full capability of ERP applications. In organizations that have installed ERP systems, the post implementation calls for intensive interactions among managers with system users consisting of knowledge creating, sharing, extraction, preservation, and learning (Tsai et al., 2011). Throughout the life of the installed application, management must periodically review the usage of the ERP application to ensure users are not reverting to legacy systems and external applications, creating islands of information. From a strategic management perspective, Maditinos et al. (2012) found when top management works closely with ERP users, the communication between business groups is enhanced, and conflict resolution becomes attainable. Based on a review of the research on technology and knowledge sharing in organizations, all stakeholders of an organization should be held accountable for attaining the long-term success of installing an ERP application.

\section{SUMMARY AND CONCLUSIONS}

A review of the literature uncovered ERP implementations continue to fail due to a number of reasons. Although researchers have concluded that top management support, user feedback, training and education, project management, and ERP package selection are factors that can mitigate the risk of failed implementations, a gap still exists (Baykasoğlu \& Gölcük, 2017; Leyh \& Sander, 2015; Shao, Feng, \& Hu, 2016; Sun, Ni, \& Lam, 2015; Tarhini, Ammar, \& Tarhini, 2015). With the lack of consensus regarding critical success factors identified in the literature versus those applied in small and medium business environments (Alshardan, Goodwin, \& Rampersad, 2015; Venkatraman \& Fahd, 2016), the goal of this literature review was to narrow the scholar-practitioner gap.

In performing a literature search on positive social change and ERP implementations, the search results uncovered the gap still exists on the research topic (Elbardan \& Kholeif, 2017; Seth, Goyal, \& Kiran, 2017). Narrowing this gap may contribute to positive social change by working toward building a consensus among practitioners and scholars to improve project success and the triple bottom line for large enterprises and small and medium enterprises.

\section{REFERENCES}

[1]. Acar, A. Z. (2012). Organizational culture, leadership styles and organizational commitment in Turkish logistics industry. Procedia - Social and Behavioral Sciences, 58(1), 217-226. doi:10.1016/j.sbspro.2012.09.995

[2]. Ahmad, N., \& Mehmood, R. (2015). Enterprise systems: Are we ready for future sustainable cities. Supply Chain Management: An International Journal, 20(3), 264-283. doi:10.1108/scm-112014-0370

[3]. Alshardan, A., Goodwin, R., \& Rampersad, G. (2015). A benefits assessment model of information systems for small organizations in developing countries. Computer and Information Science, 9(1), 1-20. doi:10.5539/cis.v9n1p1 
[4]. Amba, S. M., \& Abdulla, H. (2014). The impact of enterprise systems on small and medium-sized enterprises in the kingdom of Bahrain. International Journal of Management and Marketing Research, 7(1), 49-57. Retrieved from http://www.theibfr.com/ijmmr.htm

[5]. Banerjee, A. (2015). Information technology enabled process re-engineering for supply chain legality. International Journal of Information Technology and Management, 14(1), 60-75. Doi:10.1504/ijitm.2015.066060

[6]. Bansal, V., \& Agarwal, A. (2015). Enterprise resource planning: Identifying relationships among critical success factors. Business Process Management Journal, 21(6), 1337-1352. Doi:10.1108/BPMJ-12-2014-0128

[7]. Baykasoğlu, A., \& Gölcük, İ. (2017). Development of a two-phase structural model for evaluating ERP critical success factors along with a case study. Computers \& Industrial Engineering, 106(1), 256-274. Doi:10.1016/j.cie.2017.02.015

[8]. Bento, A. [Al], Bento, R., \& Bento, A. [Ana]. (2015). How fast are enterprise resource planning (ERP) systems moving to the cloud? Journal of Information Technology Management, 26(4), 3544. Retrieved from https://jitm.ubalt.edu/

[9]. Bhuiyan, F., Chowdhury, M. M., \& Ferdous, F. (2014). Historical evolution of human resource information system (HRIS): An interface between HR and computer technology. Human Resource Management Research, 4(4), 75-80. Retrieved from http://journal.sapub.org/hrmr

[10]. Bohórquez, V., \& Esteves, J. (2008). Analyzing SMEs as a moderator of ERP impact in SMEs' productivity. Communications of the IIMA, 8(3), 67-80. Retrieved from http://repositorio.ulima.edu.pe/

[11]. Brumberg, R., Kops, E., Little, E., Gamble, G., Underbakke, J., \& Havelka, D. (2016). Stalled ERP at random textiles. Information Systems Education Journal, 14(2), 49-57. Retrieved from http://isedj.org/

[12]. Chawla, A., \& Sujatha, R. (2015). Explore, excite and expand leadership capacity lived experiences of present day leaders on leadership training and development in India. International Journal of Academic Research in Business and Social Sciences, 5(9), 64-78. Doi:10.6007/ijarbss/v5i $9 / 1814$

[13]. Chofreh, A. G., Goni, F. A., Ismail, S., Shaharoun, A. M., Klemeš, J. J., \& Zeinalnezhad, M. (2016). A master plan for the implementation of sustainable enterprise resource planning systems (part one): Concept and methodology. Journal of Cleaner Production, 136, 176-182.

Doi:10.1016/j.jclepro.2016.05.140
[14]. Chofreh, A. G., Goni, F. A., Shaharoun, A. M., Ismail, S., \& Klemeš, J. J. (2014). Sustainable enterprise resource planning: Imperatives and research directions. Journal of Cleaner Production, 71, 139-147. doi:10.1016/j.jclepro.2014.01.010

[15]. De Soete, W. (2016). Towards a multidisciplinary approach on creating value: Sustainability through the supply chain and ERP systems. Systems, 4(1), 16-26. doi:10.3390/systems4010016

[16]. Dunn, T. E., Lafferty, C. L., \& Alford, K. L. (2012). Global leadership: A new framework for a changing world. S.A.M. Advanced Management Journal, 77(2), 4-14. Retrieved from http://samnational.org/

[17]. Egdair, I. M., Rajemi, M. F., \& Nadarajan, S. (2015). Technology factors, ERP system and organization performance in developing countries. International Journal of Supply Chain Management, 4(4), 82-89. Retrieved from http://ojs.excelingtech.co.uk/index.php/IJSCM

[18]. Elbardan, H., \& Kholeif, A. O. (2017). ERP, internal auditing and corporate governance. Enterprise Resource Planning, Corporate Governance and Internal Auditing, 12(5), 13-54. doi:10.1007/978-3-319-54990-3_2

[19]. Elkhani, N., Soltani, S., \& Ahmad, M. N. (2014). The effects of transformational leadership and ERP system self-efficacy on ERP system usage. Journal of Enterprise Information Management, 27(6), 759-785. doi:10.1108/jeim-06-2013-0031

[20]. Fadlalla, A., \& Amani, F. (2015). A keywordbased organizing framework for ERP intellectual contributions. Journal of Enterprise Information Management, 28(5), 637-657. doi:10.1108/jeim09-2014-0090

[21]. Flynn, C. B., Smither, J. W., \& Walker, A. G. (2015). Exploring the relationship between leaders' core self-evaluations and subordinates' perceptions of servant leadership: A field study. Journal of Leadership \& Organizational Studies, 23(3), 260-271. doi:10.1177/1548051815621257

[22]. García-Morales, V. J., Jiménez-Barrionuevo, M. M., \& Gutiérrez-Gutiérrez, L. (2012).

Transformational leadership influence on organizational performance through organizational learning and innovation. Journal of Business Research, 65(7), 1040-1050. doi:10.1016/j.jbusres.2011.03.005

[23]. Gianni, M., Gotzamani, K., \& Tsiotras, G. (2017). Multiple perspectives on integrated management systems and corporate sustainability performance. Journal of Cleaner Production, 168(1), $1297-$ 1311. doi:10.1016/j.jclepro.2017.09.061

[24]. Greenleaf, R. K. (1970). The servant as leader. Newton Centre, MA: Robert K. Greenleaf Center. Greenleaf, R. K. (1977). Servant leadership: A journey into the nature of legitimate power and greatness. New York, NY: Paulist Press. 
[26]. Hall, K. K., Baker, T. L., Andrews, M. C., Hunt, T. G., \& Rapp, A. A. (2015). The importance of product/service quality for frontline marketing employee outcomes: The moderating effect of leader-member exchange (LMX). Journal of Marketing Theory and Practice, 24(1), 23-41. doi:10.1080/10696679.2016.1089762

[27]. Harvey, M., \& Buckley, M. R. (2002). Assessing the "conventional wisdoms" of management for the 21st century organization. Organizational Dynamics, 30(4), 368-378. doi:10.1016/s00902616(02)00062-1

[28]. Hassan, H., Asad, S., \& Hoshino, Y. (2016). Determinants of leadership style in big five personality dimensions. Universal Journal of Management, 4(4), 161-179.

doi:10.13189/ujm.2016.040402

[29]. Hsu, P. F., Ray, S., \& Li-Hsieh, Y. Y. (2014). Examining cloud computing adoption intention, pricing mechanism, and deployment model. International Journal of Information Management, 34(4), 474-488.

doi:10.1016/j.ijinfomgt.2014.04.006

[30]. Huin, S. (2004). Managing deployment of ERP systems in SMEs using multiagents. International Journal of Project Management, 22(6), 511-517. doi:10.1016/j.ijproman.2003.12.005

[31]. Iveroth, E. (2016). Strategies for leading ITenabled change: Lessons from a global transformation case. Strategy \& Leadership, 44(2), 39-45. doi:10.1108/sl-06-2015-0050

[32]. Jacobs, F. R., \& Weston, F. (2007). Enterprise resource planning (ERP) - A brief history. Journal of Operations Management, 25(2), 357-363. doi:10.1016/j.jom.2006.11.005

[33]. Jeng, D., \& Dunk, N. (2013). Knowledge management enablers and knowledge creation in ERP system success. International Journal of Electronic Business Management, 11(8), 49-59. Retrieved from http://ijebmojs. ie.nthu.edu.tw/IJEBM_OJS/index.php/IJEBM

[34]. Kasemsap, K. (2016). Multifaceted applications of data mining, business intelligence, and knowledge management. International Journal of Social and Organizational Dynamics in IT, 5(1), 57-69. doi:10.4018/ijsodit.2016010104

[35]. Kennedy, K. (2012). A comprehensive global leadership model. Business Renaissance Quarterly, 7(1), 75-106. Retrieved from http://www.brqjournal.com/

[36]. Krog, C. L., \& Govender, K. (2015a, November 12-13). Servant leadership and project management: Examining the effects of leadership style on project success. Presented at the European Conference on Management, Leadership \& Governance, Lisbon, Portugal. Retrieved from http://www.academicconferences. org/conferences/ecmlg/ecmlg-future-and-past/

[37]. Krog, C. L., \& Govender, K. (2015b). The relationship between servant leadership and employee empowerment, commitment, trust and innovative behaviour: A project management perspective. SA Journal of Human Resource Management, 13(1), 1-12.

doi:10.4102/sajhrm.v13i1.712

[38]. Kumar, K., \& Van Hillegersberg, J. (2000). ERP experiences and evolution. Communications of the $A C M, 43(4), 23-26$. Retrieved from https://cacm.acm.org/

[39]. Larteb, L., Benhadou, M., Haddout, A., \& Nahla, H. (2016). The key to lean performance: Implementing a daily shop-floor control system using standardization and visual management.

Journal of Advanced Research in

[40]. Management, 7(1), 34-43. Retrieved from https://journals.aserspublishing.eu/jarm

[41]. Le Pennec, M., \& Raufflet, E. (2016). Value creation in inter-organizational collaboration: An empirical study. Journal of Business Ethics, 16(1), 1-18. doi:10.1007/s10551-015-3012-7

[42]. Leyh, C., \& Sander, P. (2015). Critical success factors for ERP system implementation projects: An update of literature reviews. Enterprise Systems: Strategic, Organizational, and Technological Dimensions, 198(1), 45-67. doi:10.1007/978-3-319-17587-4_3

[43]. Lin, H. (2010). An investigation into the effects of IS quality and top management support of ERP system usage. Total Quality Management \& Business Excellence, 21(3), 335-349. doi:10.1080/14783360903561761

[44]. Maas, J., Fenema, P. C., \& Soeters, J. (2014). ERP system usage: The role of control and empowerment. New Technology, Work and Employment, 29(1), 88-103. doi:10.1111/ntwe. 12021

[45]. Maditinos, D., Chatzoudes, D., \& Tsairidis, C. (2012). Factors affecting ERP system implementation effectiveness. Journal of Enterprise Information Management, 25(1), 6078. doi:10.1108/17410391211192161

[46]. Mahdavian, M., Wingreen, S. C., \& Ghlichlee, B. (2016). The influence of key users' skills on ERP success. Journal of Information Technology Management, 27(2), 48-64. doi:10.1007/s00170013-5144-1

[47]. May, J., Dhillon, G., \& Caldeira, M. (2013). Defining value-based objectives for ERP systems planning. Decision Support Systems, 55(1), 98109. doi:10.1016/j.dss.2012.12.036

[48]. Minner, W. (2015). Leading global organizations. Journal of Management Policy and Practice, 16(2), 122-126. Retrieved from http://www.nabusinesspress.com/jmppopen.html

[49]. Mitra, P., \& Mishra, S. (2016). Behavioral aspects of ERP implementation: A conceptual review. Interdisciplinary Journal of Information, Knowledge, and Management, 11(1), 17-30. Retrieved from http://www.informingscience.org/Journals/IJIKM/ 
[50]. Mittal, S. (2016). Effects of transformational leadership on turnover intentions in IT SMEs. International Journal of Manpower, 37(8), 13221346. doi:10.1108/IJM-10-2014-0202

[51]. Ndalila, P., Mjema, E. A., Kundi, B. A., \& Kerefu, L. J. (2015). Human resource competency structure for organizational innovation leadership in engineeringbased research and development institutions in Tanzania. Journal of Multidisciplinary Engineering Science and Technology, 2(7), 1695-1702. Retrieved from http://www.jmest.org/

[52]. Palanisamy, R., Verville, J., \& Taskin, N. (2015). The critical success factors (CSFs) for enterprise software contract negotiations. Journal of Enterprise Information Management, 28(1), 3459. doi:10.1108/jeim-12-2013-0083

[53]. Pishdad, A., Koronios, A., Reich, B. H., \& Geursen, G. (2014). ERP institutionalisation- A quantitative data analysis using the integrative framework of IS theories. Journal of Information Systems, 18(3), 347-369. doi:10.3127/ajis.v18i3.1089

[54]. Ranjan, S., Jha, V. K., \& Pal, P. (2016). A strategic and sustainable multi-criteria decision making framework for ERP selection in OEM. International Journal of Applied Engineering Research, 11(3), 1916-1926. Retrieved from https://www.ripublication.com/ijaer.htm

[55]. Ravasan, A., \& Mansouri, T. (2016). A dynamic ERP critical failure factors modelling with FCM throughout project lifecycle phases. Production Planning \& Control, 27(2), 65-82. doi:10.1080/09537287.2015.1064551

[56]. Razzhivina, M. A., Yakimovich, B. A., \& Korshunov, A. I. (2015). Application of information technologies and principles of lean production for efficiency improvement of machine building enterprises. Pollack Periodica, 10(2), 1723. doi:10.1556/606.2015.10.2.2

[57]. Rezania, D., \& Ouedraogo, N. (2013).

Organization development through ad hoc problem solving. International Journal of Managing Projects in Business, 7(1), 23-42. doi:10.1108/ijmpb-11-2012-0067

[58]. Salimi, F., Dankbaar, B., \& Davidrajuh, R. (2015). A comprehensive study on the differences between MRP and ERP implementation. Communications of the IIMA, 6(1), 83-93. Retrieved from http://www.iima.org/

[59]. Scandura, T. A., \& Pellegrini, E. K. (2008). Trust and leader-member exchange: A closer look at relational vulnerability. Journal of Leadership \& Organizational Studies, 15(2), 101-110. doi:10.1177/1548051808320986
[60]. Seth, M., Goyal, D. P., \& Kiran, R. (2017).

Diminution of impediments in implementation of supply chain management information system for enhancing its effectiveness in Indian automobile industry. Journal of Global Information Management, 25(3), 1-20. doi:10.4018/jgim.2017070101

[61]. Shao, Z., Feng, Y., \& Hu, Q. (2016). Effectiveness of top management support in enterprise systems success: A contingency perspective of fit between leadership style and system life-cycle. European Journal of Information Systems, 25(2), 131-153. doi:10.1057/ejis.2015.6

[62]. Shao, Z., Wang, T., \& Feng, Y. (2015). Impact of organizational culture and computer self-efficacy on knowledge sharing. Industrial Management \& Data Systems, 115(4), 590-611. doi:10.1108/IMDS-12-2014-037

[63]. Singh, A., \& Nagpal, S. (2014). Implementation of ERP in cloud computing. International Journal of Scientific \& Technology Research, 3(10), 100-103. Retrieved from www.ijstr.org

[64]. Solutions, P. C. (2016). 2016 report on ERP systems and enterprise software. 1-32. Retrieved from http://panorama-consulting.com/resourcecenter/2016-erp-report/

[65]. Sudhaman, P., \& Thangavel, C. (2015). Efficiency analysis of ERP projects - software quality perspective. International Journal of Project Management, 33(4), 961-970. doi:10.1016/j.ijproman.2014.10.011

[66]. Sun, H., Ni, W., \& Lam, R. (2015). A step-by-step performance assessment and improvement method for ERP implementation: Action case studies in Chinese companies. Computers in Industry, 68(1), 40-52. doi:10.1016/j.compind.2014.12.005

[67]. Tarhini, A., Ammar, H., \& Tarhini, T. (2015). Analysis of the critical success factors for enterprise resource planning implementation from stakeholders' perspective: A systematic review. International Business Research, 8(4), 25-40. doi:10.5539/ibr.v8n4p25

[68]. Thakur, M. A. (2016). Enterprise resource planning (ERP) implementation in technical educational institutes: Prospects and challenges. International Journal of Multifaceted and Multilingual Studies, 3(2), 1-5. Retrieved from www.ijmms.in

[69]. Tsai, M., Li, E., Lee, K., \& Tung, W. (2011). Beyond ERP implementation: The moderating effect of knowledge management on business performance. Total Quality Management \& Business Excellence, 22(2), 131-144. doi:10.1080/14783363.2010.529638

[70]. Upadhyay, P., Basu, R., Adhikary, R., \& Dan, P. K. (2010). A comparative study of issues affecting ERP implementation in large scale and small medium scale enterprises in India: A Pareto approach. International Journal of Computer Applications, 8(3), 23-28. doi:10.5120/1192-1670 
[71]. Venkatraman, S., \& Fahd, K. (2016). Challenges and success factors of ERP systems in Australian SMEs. Systems, 4(2), 1-18.

doi:10.3390/systems4020020

[72]. Verdouw, C., Robbemond, R., \& Wolfert, J. (2015). ERP in agriculture: Lessons learned from the Dutch horticulture. Computers and Electronics in Agriculture, 114(1), 125-133. doi:10.1016/j.compag.2015.04.002

[73]. Zach, O., \& Munkvold, B. E. (2012). Identifying reasons for ERP system customization in SMEs: A multiple case study. Journal of Enterprise Information Management, 25(5), 462-478. doi:10.1108/17410391211265142

[74]. Zvezdov, D., \& Hack, S. (2016). Carbon footprinting of large product portfolios. Extending the use of enterprise resource planning systems to carbon information management. Journal of Cleaner Production, 135(1), 1267-1275. doi:10.1016/j.jclepro 